University of Nebraska - Lincoln

DigitalCommons@University of Nebraska - Lincoln

Daugherty Water for Food Global Institute:

Faculty Publications

2021

Surveillance of plasticizers, bisphenol A, steroids and caffeine in

surface water of River Ganga and Sundarban wetland along the Bay of Bengal: occurrence, sources, estrogenicity screening and ecotoxicological risk assessment

Paromita Chakraborty

Nancy W. Shappell

Moitraiyee Mukhopadhyay

Sathaporn Onanong

Daniel D. Snow

Follow this and additional works at: https://digitalcommons.unl.edu/wffdocs

Part of the Environmental Health and Protection Commons, Environmental Monitoring Commons, Hydraulic Engineering Commons, Hydrology Commons, Natural Resource Economics Commons, Natural Resources and Conservation Commons, Natural Resources Management and Policy Commons, Sustainability Commons, and the Water Resource Management Commons

This Article is brought to you for free and open access by the Daugherty Water for Food Global Institute at DigitalCommons@University of Nebraska - Lincoln. It has been accepted for inclusion in Daugherty Water for Food Global Institute: Faculty Publications by an authorized administrator of DigitalCommons@University of Nebraska Lincoln. 


\title{
Surveillance of plasticizers, bisphenol A, steroids and caffeine in surface water of River Ganga and Sundarban wetland along the Bay of Bengal: occurrence, sources, estrogenicity screening and ecotoxicological risk assessment
}

\author{
Paromita Chakraborty, ${ }^{1,2}$ Nancy W. Shappell, ${ }^{3}$ \\ Moitraiyee Mukhopadhyay, ${ }^{2}$ Sathaporn Onanong, ${ }^{4}$ \\ K. Ronnie Rex, ${ }^{2}$ and Daniel Snow ${ }^{4}$ \\ 1 Department of Civil Engineering, SRM Institute of Science and Technology, \\ Kancheepuram district, Tamil Nadu 603203, India \\ 2 SRM Research Institute, SRM Institute of Science and Technology, \\ Kancheepuram district, Tamil Nadu 603203, India \\ 3 Retired from Agricultural Research Service, Edward T. Schafer Agricultural \\ Research Center, Biosciences Research Laboratory, 1616 Albrecht Blvd., Fargo, \\ ND, 58102, United States \\ 4 Water Sciences Laboratory, University of Nebraska-Lincoln, Lincoln, NE 68583 \\ United States \\ Corresponding author - P. Chakraborty, email paromita.c@res.srmuniv.ac.in, \\ parochakraborty@gmail.com
}

\begin{abstract}
The transboundary River Ganga serves as a conduit for meltwater from the Himalayas and is a major freshwater source for two thirds of Indian population before emptying into the Sundarban Delta, the largest estuary in the Bay of Bengal. Endocrine disrupting compounds (EDCs) such as phthalic acid esters (PAEs) and bisphenol A (BPA) used as organic plastic additives can pollute the aquatic environment receiving plastic
\end{abstract}

Published in Water Research 190 (2021) 116668

https://doi.org/10.1016/j.watres.2020.116668

Copyright (C) 2020 Elsevier Ltd. Used by permission.

Submitted 1 April 2020; revised 10 November 2020; accepted 21 November 2020; published

23 November 2020. 
litter. Hence, we have investigated these EDCs in water samples from Ganga and Sundarban wetland of India. Since these compounds exhibit estrogenic potential, we have further measured steroids and evaluated the estrogenic activity (estradiol equivalents, Bio E2Eqs) using an in-vitro bioassay (E-Screen). Further Bio E2Eqs were compared with the sum of predicted estradiol equivalents based on the chemical concentrations of PAEs and BPA by E-Screen (Chem E2Eq) and YES factors (Chem YES). Caffeine was measured as a marker for anthropogenic wastewater discharge. Results showed that the highest Bio E2Eq (below the lowest observable effect of E2 on fish) was associated with sites having sewer outfalls in the middle stretch of the river, and concomitantly coinciding with the elevated concentrations of caffeine. Neither Chem E2Eq nor Chem YES correlated with measured Bio E2Eqs. River concentrations of BPA (0.04-4.46 $\mu \mathrm{g} / \mathrm{L})$ and $\Sigma_{7}$ plasticizers $(0.43-7.63 \mu \mathrm{g} / \mathrm{L})$ were higher than BPA $(0.21-2.82 \mu \mathrm{g} / \mathrm{L})$ and $\Sigma_{7}$ plasticizers $(0.85-2 \mu \mathrm{g} / \mathrm{L})$ in the Sundarban wetland. The only steroids detected were androgens, found at four sites in Ganga $(0.007 \mu \mathrm{g} / \mathrm{L} \pm 0.003$, mean \pm S.D. $)$. The highest estimated ecotoxicological risk to aquatic insect and fish stemmed from BPA. A secondary effect, and a potential impact on human health could be reflected via fish consumption from the productive fisheries region along the lower stretch of River Ganga. Identification of areas of elevated estrogenicity, plasticizer and steroid concentrations in River Ganga can be used to design and implement interventions for the remediation of such emerging contaminants.

Keywords: Ganga, Sundarban, Endocrine disrupting chemicals, Caffeine, Estrogenic activity

\section{Introduction}

The transboundary, perennial River Ganga rises on the southern slopes of the Himalayan Range and before emptying into the Bay of Bengal forms the world's largest delta known as the Ganges Delta or Sundarban Delta. Sundarban is the world's largest mangrove ecosystem on the seaward side of the Ganges Delta. The river basin of Ganga is the largest in India covering nearly one fourth of land mass and supports $43 \%$ of Indian population ( 530 million) (GRBEMP, 2013). One third of the India's urban population lives in the towns along the Ganga River Basin.

The impact of point sources of pollution in this important water supply depends on the velocity and the dilution capacity of the river. The increasing magnitude of these inputs threaten further degradation of the riverine environment. River Ganga in its total length of over $2500 \mathrm{~km}$ receives industrial effluents of 501 million litres per day (MLD) from 764 grossly polluting industries (GPI) (CPCB, 2013b). Out of ten rivers in the world, River Ganga is one of the top three rivers carrying $90 \%$ of plastic 
wastes other than the Indus and the Brahmaputra (Schmidt et al., 2017). Phthalic acid esters (PAEs) and bisphenol A (BPA) are the intermediates added to manmade plastic or polymers to improve their flexibility, durability and adhesion properties in epoxy resins, polycarbonate and polyvinyl chloride (PVC) products. Such plasticizers have been observed in the industrial corridor of Ganga (Chakraborty et al., 2019a). Globally, an increasing demand has been observed in the use of such synthetic plasticizers by the plastic manufacturing industry and is expected to reach approximately 9.75 million tons (MT) in 2024 (Wei et al., 2019).

The practices of burning man-made plastic products in open dumpsites and unregulated electronic waste (e-waste) recycling in Indian cities (Chakraborty et al., 2019b) are other ways environment is contaminated. These practices disperse plasticizers that are only physically bound to polymeric matrices. Evidence of such a contamination is the presence of both PAEs and BPA, with dominance of relatively higher molecular weight PAE such as bis (2-ethylhexyl) phthalate (DEHP) in the surface riverine sediment along the lower stretch of River Ganga (Chakraborty et al., 2019a). Additional release of various plastic additives and plasticizers in the water bodies resulted from multitude of sources, such as wastewater from industrial and domestic sources, run-off, atmospheric deposition and leaching from microplastics due to accumulation and degradation of plastic debris (Hermabessiere et al., 2017).

Many plasticizers are endocrine disrupting chemicals (EDCs) with the ability to mimic the naturally occurring hormones due to their structural resemblance (Vilela et al., 2018). In addition, the relatively higher molecular weight phthalates such as DEHP, di-n-butyl phthalate (DnBP), diisononyl phthalate (DiNP) are suspected carcinogens, as well as toxic to liver, kidney (Gomez-Hens and Aguilar-Caballos, 2003) and reproductive organs (Swan, 2008). The importance of monitoring these type of pollutants was recognized by the United States Environmental Protection Agency (USEPA, 2014), European Communities (EC, 1994, 1995, 1997) and China (PRC-NS, 2002) where six plasticizers viz., DMP, DEP, DnBP, BBP, DEHP and DnOP were marked as priority pollutants due to their effects on specific endocrine systems. Due to the increasing inputs and potential ecological impacts of EDCs in aquatic environment, we conducted a surveillance of selected EDCs in River Ganga and Sundarban Wetland in India. Caffeine was used as a marker for the co-occurrence of organic compounds from untreated anthropogenic wastewater 
including plasticizers and other emerging EDCs (Moore et al., 2008 ; Quinn et al., 2009 ; Richards and Cole, 2006 ; Smith and Burgett, 2005). The "E-Screen" assay (Shappell et al., 2016) was used to determine the estrogenic activity in extracts from the river and wetland samples.

Hence, the major objectives of this study were to (i) measure the levels and mass flow of plasticizers such as priority PAEs, bis (2-ethylhexyl) adipate (DEHA), BPA, steroid hormones and caffeine (ii) elucidate the spatial distribution and sources of PAEs, BPA and caffeine using multivariate principal component analysis and compositional profiles (iii) experimentally measure the estrogenicity of each sample by using an in-vitro assay (E-Screen) (iv) report the estimated theoretical or predicted estrogenicity associated with plasticizers and BPA in surface water, and (v) assess the stretch wise ecotoxicological risk to various aquatic organisms in surface water of River Ganga and Sundarban wetland.

\section{Materials and methods}

\subsection{Sample collection}

The entire length of River Ganga can be divided into three distinct stretches before meeting the Bay of Bengal (BOB). In the upper stretch of Ganga, the sampling sites were from the state of Uttarakhand (UK) with the highest urban population (30\%) among other states in Ganga River Basin. In this stretch, 127.5 MLD of wastewater generated by 42 GPI along with 158 MLD of domestic sewage are discharged directly into the major stem of the river (Fig. 1). In the middle stretch, the river flows and meanders mainly along with a bed of fine sand through the state of Uttar Pradesh. This stretch included the major sampling sites from Uttar Pradesh including the holy cities of Allahabad (station 7) and Varanasi (station 8). Uttar Pradesh has an urban population of $23 \%$ with a density of 828 persons $/ \mathrm{km}^{2}$. Due to the distinct tidal influence, the lower stretch is a "well-mixed" estuarine system. Sundarban wetland (SBW) is a vast stretch of tidal mangrove forests and swampland with a population of about 4.37 million and a density of 1082 persons $/ \mathrm{km}^{2}$ within the deltaic region which is crisscrossed by major rivers and their tributaries and creeks, which flow out to the BOB. 


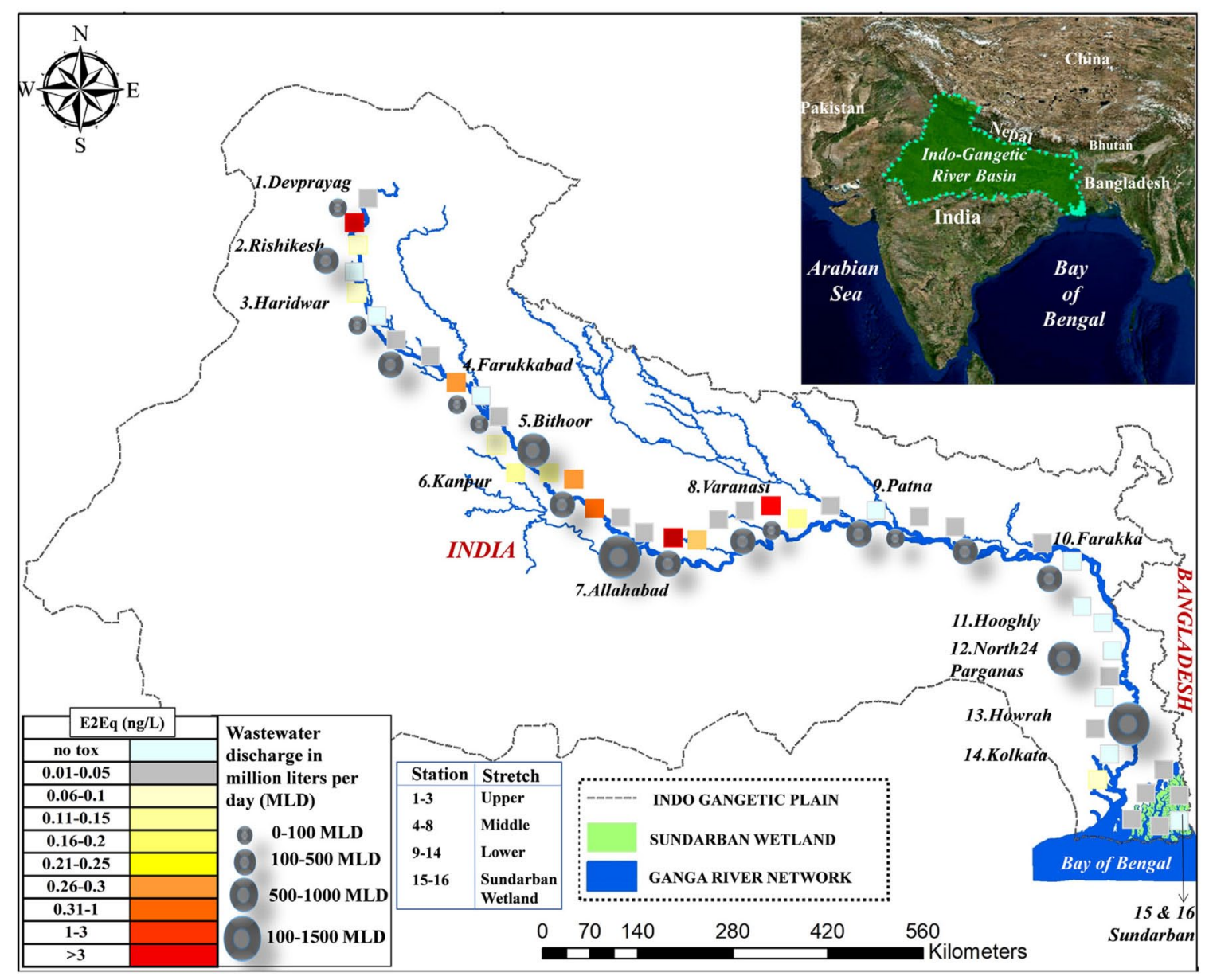

Fig. 1. Map representing sampling stations from upper, middle and lower stretches of River Ganga, Sundarban wetlands, and wastewater discharge outfalls via open drains in proximity to stations and respective BioE2Eq and wastewater discharge volumes.

Surface water samples were collected from sixteen stations covering dry period during last part of the pre-monsoonal phase in March 2017 from the aforementioned four stretches, upper stretch $(n=8)$, middle stretch $(n=17)$, lower stretch $(n=13)$ along the River Ganga and Matla and Bidyadhari rivers in SBW $(n=6)$ along the BOB (Fig. 1). Details regarding each sampling site are given in Supporting Information (SI) Table S1. Surface water sample collection procedures are described elsewhere (Chakraborty et al., 2016). Briefly, composite water sample of $1 \mathrm{~L}$ from each site was prepared after mixing 5 samples $(1 \mathrm{~L}$ each) over a length of $500 \mathrm{~m}$ from each site. The sampling sites were 
selected to obtain a general picture of the range of contamination in the aquatic environment of River Ganga and SBW. Samples were collected in $1 \mathrm{~L}$ amber glass bottles and extracted on the same day of collection to reduce the chances for contamination and to minimize degradation of contaminants.

\subsection{Chemicals and reagents}

A solution of plasticizers containing seven plasticizers (dimethyl phthalate (DMP), di-ethyl phthalate (DEP), di-n-butyl phthalate (DnBP), benzyl butyl phthalate (BBP), di-n-octyl phthalate (DnOP), bis(2-ethylhexyl) phthalate (DEHP) and bis(2-ethylhexyl) adipate (DEHA)) at $1000 \mathrm{mg} / \mathrm{L}$ was purchased from Supelco Analytical (Philadelphia, PA, USA). BPA standard was procured from Sigma Aldrich (St. Louis, MO). Labeled standards of ${ }^{13} \mathrm{C}$-caffeine, ${ }^{13} \mathrm{C}$-DEHP and ${ }^{13} \mathrm{C}$ BPA were obtained from Cambridge Isotope Laboratories (Andover, MA, USA). Reference standards of $17 \alpha$-estradiol and estriol were purchased from Fisher (St. Louis, MO), while 4-androstenedione, 17 $\alpha$-hydroxyprogesterone, $17 \alpha$-trenbolone, $\alpha$-zearalanol, $\alpha$-zearalenol, $17 \beta$-estradiol, $17 \beta$-trenbolone, $\beta$-zearalanol, $\beta$-zearalenol, androstenedienedione, androsterone, epitestosterone, estrone, ethynylestradiol, melengesterolacetate, progesterone, testolactone and testosterone were purchased from Sigma-Aldrich (St. Louis, MO). Working standard solutions for calibration and recovery spikes were prepared from the stock standard solutions and stored at $-20{ }^{\circ} \mathrm{C}$.

\subsection{Extraction}

\subsubsection{Plasticizers and $B P A$}

Water samples were subjected to solid phase extraction (SPE) using the method given by Gatidou et al. (2007). Briefly, $1 \mathrm{~L}$ of sample was spiked with 20 ng of ${ }^{13} \mathrm{C}$-DEHP and ${ }^{13} \mathrm{C}$-BPA and extracted using $500 \mathrm{mg}$ of C18 cartridges (BondElut, Agilent technologies). Each cartridge was pre-conditioned by using $6 \mathrm{~mL}$ of methanol and $2 \times 3.5 \mathrm{~mL}$ of milli-Q water at the rate of $0.5 \mathrm{~mL} / \mathrm{min}$. One liter of sample was passed through the column at the rate of $10 \mathrm{~mL} / \mathrm{min}$. Stepwise column elution $(4 \times 2 \mathrm{~mL}$ of dichloromethane: $\mathrm{n}$-hexane, $4: 1 ; \mathrm{v} / \mathrm{v}$ ) was followed by moisture removal via passage through a column of anhydrous sodium sulfate. The final 
solution was reduced to $1 \mathrm{~mL}$ using dry nitrogen. For BPA analysis, samples were derivatized with N-methyl-N-(trimethylsilyl) trifluoroacetamide (MSTFA) prior to instrumental analysis.

\subsubsection{Steroids and caffeine}

Samples were extracted using the method given by Ye et al., 2007. Briefly, $5 \mathrm{~g} / \mathrm{L}$ disodium ethylenediaminetetraacetic acid (Na 2 EDTA) was added to each $1 \mathrm{~L}$ sample, spiked with $20 \mathrm{ng}$ of ${ }^{13} \mathrm{C}$-caffeine, and then passed through a preconditioned $6 \mathrm{~mL} 200 \mathrm{mg}$ of hydrophilic-lipophilic balance (HLB) cartridges (Waters Inc., Milford, MA) at a flow rate of $5 \mathrm{~mL} /$ min. For preconditioning, $6 \mathrm{~mL}$ of methanol, $3 \mathrm{~mL}$ of acidified methanol $(0.1 \%$ formic acid in high pressure liquid chromatography (HPLC) grade methanol $(\mathrm{v} / \mathrm{v})$, and $2 \times 6 \mathrm{~mL}$ of laboratory grade water (LGW) were used. Labeled cartridges were air dried and stored at $4{ }^{\circ} \mathrm{C}$ until further processing.

SPE cartridges (HLB) were eluted at the University of Nebraska Water Sciences Laboratory (Lincoln, NE USA) using $5 \mathrm{~mL} \mathrm{0.5 \%} \mathrm{formic} \mathrm{acid}$ in Optima (Thermofisher Scientific, St. Louis, MO USA) grade methanol, followed with $3 \mathrm{~mL}$ Optima grade acetone. Cartridge extracts were spiked with $100 \mu \mathrm{L}$ of $1 \mathrm{ng} / \mu \mathrm{L}$ (100 ng) of internal standards for both caffeine and steroid hormone analysis (D'Alessio et al., 2018). Extracts were concentrated by evaporation to dryness under a stream of dry nitrogen gas and reconstituted by adding methanol and deionized water at a final mix of 80:20 (v/v) for caffeine and 50:50 (v/v) for steroid hormone analysis.

\subsection{Instrumental analysis}

\subsubsection{Gas chromatography-mass spectrometry}

PAEs, DEHA and BPA were detected and quantified using Agilent 7890B Gas Chromatography and 5977A MS using HP-5 column (30 $\mathrm{m} \times$ $0.25 \mathrm{mmi} . \mathrm{d} . \times 0.25 \mu \mathrm{m}$ film thickness). Detector temperature was maintained at $280^{\circ} \mathrm{C}$. The column temperature program was initiated at 100 ${ }^{\circ} \mathrm{C}$ for $2 \mathrm{mins}$, increased to $150^{\circ} \mathrm{C}$ at a rate of $10^{\circ} \mathrm{C} / \mathrm{min}$ and further increased to $300^{\circ} \mathrm{C}$ at the rate of $8{ }^{\circ} \mathrm{C} / \mathrm{min}$ with a holding time of $10 \mathrm{mins}$. The flow rate of the carrier gas He (99.999\% purity) was kept constant at $1.5 \mathrm{~mL} / \mathrm{min}$. The extracts $(1 \mu \mathrm{L})$ were injected into GC in split-less mode with an inlet temperature of $250^{\circ} \mathrm{C}$. The mass spectrometer was operated in electron ionization (EI) mode at $70 \mathrm{eV}$ and at an emission 
current of $60 \mu$ A. Full scan data was obtained in a mass range of $m / z 50-$ 500 . For BPA, the detector temperature was maintained at $280^{\circ} \mathrm{C}$. The column temperature was set at $100^{\circ} \mathrm{C}$ for $1 \mathrm{~min}$, increased to $200^{\circ} \mathrm{C}$ at a rate of $20^{\circ} \mathrm{C} / \mathrm{min}$ and further increased to $250^{\circ} \mathrm{C}$ at the rate of $10^{\circ} \mathrm{C} /$ min with a holding time of 3 mins. Mass ions are reported in Table S2.

\subsubsection{Liquid chromatography-tandem mass spectrometry}

Steroids and caffeine were quantified using a Quattro-Micro tandem mass spectrometer (Waters Corporation, Milford, MA, USA) by two different instrumental methods. Steroid hormones were analyzed using atmospheric pressure photoionization (Snow et al., 2013) while caffeine detection used electrospray ionization (D’Alessio et al., 2018). Details of the steroid hormone method are published previously (Snow et al., 2013). A table of the internal standards and 16 steroids measured in extracts is included in Table S3 with multiple reaction monitoring transitions, source conditions, retention times and instrument detection limits. Caffeine was analyzed separately using a HyPurity C18 HPLC column $(250 \mathrm{~mm} \times 2.1 \mathrm{~mm} \times 5 \mu \mathrm{m}$ particle size, Thermo-Scientific, Waltham, MA, USA) at a temperature of $50^{\circ} \mathrm{C}$ and flow rate of 0.20 $\mathrm{mL} / \mathrm{min}$, while steroids were separated using a BetaBasic C18 reverse phase HPLC column $(250 \mathrm{~mm} \times 2.1 \mathrm{~mm}, \times 5 \mu \mathrm{m}$ particle size, ThermoScientific, Waltham, MA, USA) at a temperature of $50^{\circ} \mathrm{C}$ and flow rate of $0.3 \mathrm{~mL} / \mathrm{min}$. Method detection limits for both methods were determined by replicate extraction and analysis of a low-level fortified blank (USEPA, 1986).

\subsection{3. $Q A / Q C$}

All glasswares were cleaned in a $1 \%$ hydrochloric acid bath, rinsed with milli-Q water and dried using a hot air oven. Anhydrous sodium sulfate was heated at $450{ }^{\circ} \mathrm{C}$ for $4 \mathrm{~h}$. All solvents including dichloromethane, nhexane, methanol, acetone and other chemicals were of HPLC and Optima grade. Limit of detection (LOD), limit of quantification (LOQ), and precision values details are given in Tables S2 and S3. The recovery of ${ }^{13} \mathrm{C}$-DEHP, ${ }^{13} \mathrm{C}$-BPA and ${ }^{13} \mathrm{C}$-caffeine were between $89-110 \%$, 87\%-107\% and $92 \%-117 \%$, respectively. For every set of 10 samples, one procedural (extraction) blank was extracted. Along with the procedural blank, instrumental blanks for every 5 samples were also run. Blank samples were below the LOD hence samples were not blank corrected. Details 
Table 1 Concentration of endocrine disrupting compounds and caffeine (in $\mu \mathrm{g} / \mathrm{L}$ ) in surface water from River Ganga and Sundarban wetland in India.

\begin{tabular}{lllll} 
Concentration $(\mu \mathrm{g} / \mathrm{L})$ & \multicolumn{2}{l}{ River Ganga $(n=38)$} & \multicolumn{2}{l}{ Sundarban wetland $(n=6)$} \\
Compounds & Range & Avg $\pm S D$ & Range & Avg $\pm S D$ \\
\hline Caffeine & $0.004-3.36$ & $0.56 \pm 0.87$ & $0.017-1.6$ & $0.3 \pm 0.6$ \\
Bisphenol A (BPA) & $0.04-4.46$ & $0.71 \pm 0.91$ & $0.21-2.82$ & $0.83 \pm 1.04$ \\
Dimethyl phthalate (DMP) & $0.03-0.05$ & $0.04 \pm 0.004$ & $0.04-0.06$ & $0.05 \pm 0.01$ \\
Diethyl phthalate (DEP) & $0.04-2.14$ & $0.38 \pm 0.47$ & ND-0.4 & $0.15 \pm 0.13$ \\
Di-n-butyl phthalate (DnBP) & ND-2.27 & $0.43 \pm 0.37$ & $0.32-0.88$ & $0.57 \pm 0.24$ \\
Benzyl butyl phthalate (BBP) & ND-0.13 & $0.09 \pm 0.03$ & ND-0.1 & $0.09 \pm 0.04$ \\
Bis (2-ethylhexyl) adipate (DEHA) & ND-0.19 & $0.09 \pm 0.05$ & ND-0.14 & $0.1 \pm 0.05$ \\
Bis (2-ethylhexyl) phthalate (DEHP) & $0.11-6.3$ & $0.54 \pm 0.97$ & $0.17-0.43$ & $0.33 \pm 0.1$ \\
Di-n-octyl phthalate (DnOP) & ND-0.05 & $0.016 \pm 0.01$ & ND-0.02 & $0.01 \pm 0.01$ \\
$\boldsymbol{\Sigma}_{7}$ plasticizers & $0.43-7.63$ & $1.6 \pm 1.24$ & $0.85-2$ & $1.3 \pm 0.41$ \\
4-Androstenedione & ND-0.0045 & $0.0005 \pm 0.0014$ & ND & ND \\
Androstanedienedione & ND-0.0155 & $0.0009 \pm 0.0035$ & ND & ND \\
\hline
\end{tabular}

of quality assurance for steroid hormone analysis, including method detection limit determination and compound recovery, are provided elsewhere and are given in Table S3 (Snow et al., 2013).

\subsubsection{Mass flow}

Mass flow for each compound was estimated based on the formula given elsewhere (Yamazaki et al., 2015). Following equation was used for the estimation of mass flow at each station of Ganga:

$$
\text { Mass flow }(\mathrm{kg} / \text { year })=C_{i} \times A d
$$

where $C_{i}$ is the average concentration of each target compound (Table 1) and $A d$ is annual discharge in $\mathrm{m}^{3} / \mathrm{s}$ obtained from published dataset (CWC, 2017).

\subsection{In-vitro-estrogenic activity (E-Screen)}

Sample extracts were diluted in cell culture media containing charcoal dextran stripped fetal bovine serum (FBS, 10\%) and assayed using MCF-7 BOS cells generously provided by Drs. Anna Soto and Carlos Sonnenschein, Tufts University School of Medicine, Boston, MA, as previously described (Shappell, 2006). Briefly, one day after plating the human mammary epithelial cells, cells were treated with diluted water 
extracts. Typically, 6 wells of cells were treated with sample extract, with one of those wells receiving E2 $\left(4 \times 10^{-12} \mathrm{M} \beta\right.$-E2 $)$ for comparison to $\beta$-E2 alone, in order to assess sample toxicity. Sample dilutions were chosen to obtain cellular responses within the linear range of the assay (typically $1 \times 10^{-12}$ to $1 \times 10^{-11} \mathrm{M} \mathrm{E}_{2}$ ) in a 5 day incubation. Cells were incubated with multiple dilutions of samples, ranging from $0.24 \mathrm{x}$ to an extreme $7.81 \mathrm{x}$ of original surface water concentration. Estradiol equivalents (E2Eqs) were determined based on a regression analysis of the $17 \beta$-E2 curve from the same experiment. Specificity of estrogenic activity in samples (E2 receptor- dependent cellular proliferation) was confirmed by use of E2-receptor antagonist ICI 182,780 (Tocris, Ellisville, MO) as previously described (Rasmussen and Nielsen, 2002). In order to derive relative E2 Equivalents (BioE2Eqs) for the various chemicals analyzed, standard curves of each chemical were prepared and tested by in-vitro estrogenic assay (E-Screen) (Figures S1 and S2), and the following formula applied.

$$
\text { Bio E2Eqs Compound } \mathrm{X}=\frac{\mathrm{EC}_{50} \text { Compound } \mathrm{X}}{\mathrm{EC}_{50} \text { Compound } \beta-\mathrm{E} 2}
$$

LOD on the plate (as in on column) is $1 \times 10^{-13} \mathrm{M}$ or $\sim 30 \mathrm{pg} / \mathrm{L}$ for EScreen and $4 \mathrm{pg} / \mathrm{L}$ in sample. The E2Eq in the current study has been evaluated based on the pNEC for estradiol of $1 \mathrm{ng} / \mathrm{L}$ for fish (Young et al., 2002).

\subsubsection{Chem E2Eq and Chem YES}

The predicted or theoretical estrogenic activity of a sample was calculated by summing the predicted activities of each chemical based on the effective concentration of each chemical (EC 50) determined by the EScreen (Table 2). Predicted or theoretical estradiol equivalents based on E-Screen (Chem E2Eq) and yeast assay reported by Céspedes et al., 2005 (Chem YES) were calculated for each site using the following formulae:

$$
\begin{aligned}
& \text { ChemE2Eq (ng/ L) }=\mathrm{C}_{\mathrm{i}} \times \mathrm{BioEq} \\
& \text { ChemYES }(\mathrm{ng} / \mathrm{L})=\mathrm{C}_{\mathrm{i}} \times \mathrm{E} 2_{\text {equiv }}
\end{aligned}
$$

where, $\mathrm{C}_{\mathrm{i}}$ is the concentration detected for each compound, BioE2Eqs and $\mathrm{E} 2{ }_{\text {equiv }}$ are the relative estrogenicity factors obtained from E-Screen in this study and from yeast assay (Céspedes et al., 2005), respectively. 


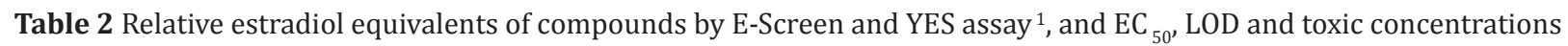
by E-Screen.

\begin{tabular}{|c|c|c|c|c|c|c|c|c|}
\hline Compounds & $\begin{array}{l}\mathrm{EC}_{50} \\
\mathrm{E}-S c r e e n \\
(\mu \mathrm{g} / \mathrm{L})\end{array}$ & $\begin{array}{l}\mathrm{EC}_{50} \\
\mathrm{YES}^{1} \\
(\mu \mathrm{g} / \mathrm{L})\end{array}$ & $\begin{array}{l}\text { Estrogenicity } \\
\text { Relative to E2 } \\
\text { E-Screen } \\
\text { (mass basis) }\end{array}$ & $\begin{array}{l}\text { Estrogenicity } \\
\text { Relative to E2 } \\
\text { YES }^{1} \\
\text { (mass basis) }\end{array}$ & $\begin{array}{l}\text { YES/ } \\
\text { E-Screen } \\
\text { E2Eq } \\
\text { (mass basis) }\end{array}$ & $\begin{array}{l}\text { Limit of } \\
\text { Detection } \\
\text { YES }^{1} \\
(\mu \mathrm{g} / \mathrm{L})\end{array}$ & $\begin{array}{l}\text { Limit of } \\
\text { Detection } \\
\text { E-Screen } \\
(\mu \mathrm{g} / \mathrm{L})\end{array}$ & $\begin{array}{l}\text { Toxicity in } \\
\text { E-Screen } \\
(\mu \mathrm{g} / \mathrm{L})\end{array}$ \\
\hline $17 \beta$-E2 & .00109 & 1 & 1 & 1 & 917 & 0.01 & 0.0001 & - \\
\hline DMP & 155 & 4080 & $3.76 \mathrm{E}-07$ & $9.804 \mathrm{E}-06$ & 26.1 & 1430 & 117 & 388 \\
\hline DEP $^{2}$ & 17.8 & 6960 & $9.99 \mathrm{E}-06$ & $5.747 \mathrm{E}-06$ & 0.58 & 2132 & 5.6 & 222 \\
\hline $\mathrm{DBP}^{2}$ & 7.0 & 3960 & $8.75 \mathrm{E}-05$ & $1.010 \mathrm{E}-05$ & 0.12 & 969 & 167.0 & 28 \\
\hline $\mathrm{BBP}$ & 625 & 5160 & $1.40 \mathrm{E}-06$ & 7.752E-06 & 5.52 & 1125 & 125 & 15,618 \\
\hline DEHA & 741 & $\mathrm{NA}^{3}$ & $1.90 \mathrm{E}-07$ & NA & NA & $\mathrm{NA}^{3}$ & 371 & 3,706 \\
\hline DEHP & 1562 & 2306 & $2.88 \mathrm{E}-07$ & $1.735 \mathrm{E}-05$ & 60.3 & 402 & 391 & 19,528 \\
\hline $\mathrm{DnOP}$ & 1172 & NA & $1.41 \mathrm{E}-07$ & NA & NA & $\mathrm{NA}^{3}$ & 781 & 7,811 \\
\hline BPA & 11.4 & 1644 & $7.21 \mathrm{E}-05$ & $2.430 \mathrm{E}-05$ & 0.34 & 490 & 1.4 & 11,415 \\
\hline Estriol & $0.0098^{2}$ & .116 & $0.15^{2}$ & 0.345 & 11.8 & 0.027 & 0.003 & - \\
\hline $17 \alpha-\mathrm{E} 2$ & 0.087 & $\mathrm{NA}^{3}$ & 0.017 & NA & NA & $\mathrm{NA}^{3}$ & 0.030 & - \\
\hline Estrone & $0.122^{2}$ & 2.12 & $0.012^{2}$ & 0.0189 & 17.4 & 0.534 & 0.030 & - \\
\hline EE2 & $0.00151^{2}$ & 0.234 & $1.4^{2}$ & 0.171 & 155 & 0.0538 & 0.00009 & - \\
\hline
\end{tabular}

1. Céspedes et al., 2005

2. Alvarez et al., 2013

3. NA, not analyzed

\subsection{Ecotoxicological risk assessment}

Values used for predicted no effect concentrations (pNEC) for different organisms were taken from Chakraborty et al., 2019a. Risk Quotient (RQ) was calculated for each organism by using the formula:

$$
\mathrm{RQ}=\frac{\mathrm{MEC}}{\mathrm{pNEC}}
$$

where MEC is the measured environmental concentration. The RQ was calculated for each site and compound. The criteria for interpreting the $\mathrm{RQ}$ are given as follows $\mathrm{RQ}<0.1$, "low risk"; $\mathrm{RQ}$ from 0.1 to 1 , "medium risk"; and RQ > 1, "high risk". pNEC values used for the organisms for each compound are given is Table S4.

\subsection{Statistical analysis}

Statistical analysis included linear regression analysis, one-way ANOVA at $95 \%$ confidence intervals, and principal component analysis using SPSS version 22 . 


\section{Results and discussion}

\subsection{Chemical concentration and mass load of plasticizers, BPA, steroids and caffeine}

In this study, we investigated 28 emerging contaminants including manmade estrogenic chemicals in the upper, middle and lower stretch of Ganga and Sundarban wetland in India (Fig. 1). Table 1, reports the concentration range and mean level of each plasticizer and BPA from this study. Comparisons of maximum concentrations from other studies have been given in supporting information (Table S5 a-d). The estimated mass flow for each plasticizers and BPA is shown in Figure S3. The average mass flow for BPA was the highest (437 kg/year) followed by DEHP (164 kg/year), DnBP (118 kg/year), caffeine (104 kg/year), DEP (63 $\mathrm{kg} /$ year), DEHA (31 kg/year), BBP (29 kg/year), DMP (16 kg/ year) and DnOP (5 kg/year).

\subsubsection{Plasticizers}

PAEs can be found at up to $60 \%$ by weight in various plastic products and represented $65 \%$ of the total plasticizers consumed globally in 2017 (Hahladakis et al., 2018). The sum of all the quantified plasticizers is a useful measure of the overall assessment of such plastic additives' contamination in water, though not as an indicator of overall toxicity, as each PAE has a unique toxicity value. Along the riverine stretch, the sum of all plasticizers was highly variable: upper mean $1.73 \pm 0.83$ SD $(0.8-3.3 \mu \mathrm{g} / \mathrm{L})$, middle $2.08 \pm 1.60(0.85-7.63 \mu \mathrm{g} / \mathrm{L})$, and lower $0.90 \pm 0.35(0.43-1.48 \mu \mathrm{g} / \mathrm{L})$. Of interest, was the finding that the wetland mean and maximum sum was higher than the lower stretch of the river $(1.30 \pm 0.41$, range $0.85-2.00 \mu \mathrm{g} / \mathrm{L})$. When compared to the sum of PAEs from previous reports, the Ganga and wetland sums are lower than the Hu River, Pearl River and Shonghua River in China (Table S5a). Of the seven reports the four with higher sums were $\sim 2$ to 3 fold higher than those reported here. Highest daily flux of 6 PAEs in the present study (291 kg/day) was approximately two fold the highest daily flux of PAEs (116 kg/day) from Rhone River in France (Schmidt et al., 2020). The total average mass flow of plasticizers was found to be $425 \mathrm{~kg} / \mathrm{yr}$. Higher abundance and elevated levels of PAEs in the surface water of River Ganga and SBW can be related to the highest density of 
plastics from fishing nets and the polythene and plastics discarded on land along the coastlines that cumulatively contributes nearly $60 \%$ of the waste reaching the oceans (NCCR, 2019). The highest DEP among all the phthalate concentrations in water from the Pearl River in China $(14,800 \mathrm{ng} / \mathrm{L})$ seems to be seven fold higher than the highest level in Ganga (2142 ng/L) (Table S5a). With the exception of BBP and DnBP (higher in the present study), the concentrations of five other plasticizers (Table 1) are comparable with the levels reported from Kaveri River in south India (Selvaraj et al., 2015). Concentrations of DnBP were up to ten fold lower than the Hun watershed (Li et al., 2015) and five fold lower than Shonghua River in China (Gao et al., 2014). DEHP concentrations were four fold lower than Yangzte River (Zhang et al., 2012) and three-fold lower than Xiaojinhe River (Wu et al., 2013), in China. Both DnBP and DEHP were comparable with Jiulong River (Li et al., 2017) in China and Tama River in Japan (Zhou and Liu, 200 0). Furthermore, DMP, DEP, BBP and DnOP concentrations were lower than those reported in Shonghua River (Gao et al., 2014) and Hun River watershed in China (Li et al., 2015), but higher than Seine River, France (Dargnat et al., 2009), Jiulong River, China (Li et al., 2017) and comparable to another French river, the Somme (Net et al., 2014).

\subsubsection{Bisphenol $A$}

BPA concentration was highly variable along different stretches of the river, with the highest concentration at a site in the middle stretch (M$17,4.46 \mu \mathrm{g} / \mathrm{L})$ and 7 of the 13 sites in the lower stretch exceeding 1 $\mu \mathrm{g} / \mathrm{L}$. Mean and range of the river stretches and wetland were: upper $0.23 \pm 0.04(0.14-0.28 \mu \mathrm{g} / \mathrm{L})$, middle $0.65 \pm 1.02(0.04-4.46 \mu \mathrm{g} / \mathrm{L})$, lower $1.08 \pm 0.93(0.86-3.12 \mu \mathrm{g} / \mathrm{L})$ and wetland $0.83 \pm 1.04(0.21-2.82 \mu \mathrm{g} / \mathrm{L})$. The average mass load for BPA in the present study (437 kg/year) was slightly higher than the total mass flow contributed by three rivers (Arakawa, Tamagawa and Edogawa) into Tokyo Bay, Japan (322 kg/year) (Yamazaki et al., 2015). Mean BPA concentration in Ganga (0.7 $\mu \mathrm{g} / \mathrm{L}$ ) was higher than Kaveri $(0.02 \mu \mathrm{g} / \mathrm{L})$ and Vellar $(0.04 \mu \mathrm{g} / \mathrm{L})$ rivers in south India (Selvaraj et al., 2014). However, the BPA concentrations in Ganga are only slightly higher than the recent study reported from Cooum 0.4 $\mu \mathrm{g} / \mathrm{L}$ ) and Adyar $(0.4 \mu \mathrm{g} / \mathrm{L})$ rivers in Chennai city, south India (Yamazaki et al., 2015), and comparable with studies from other Asian countries (Basheer et al., 2005 ; Ding and Wu, 2000; Dong et al., 2009; Huang et al., 
2012). Several studies have reported high concentrations of BPA in surface water of rivers from Taiwan ( $45 \mu \mathrm{g} / \mathrm{L}$; (Lee et al., 2013), Elba River, Germany ( $92 \mu \mathrm{g} / \mathrm{L}$; (Stachel et al., 2003) and USA ( $8 \mu \mathrm{g} / \mathrm{L}$; (Staples et al., 2000). Prevalence of BPA contamination is evident when compared with values reported from other locales. Of 17 reported mean BPA across the world, 16 were lower than those from River Ganga (Table S5b). Of the 54 maximum BPA concentrations reported in Table S5b, only four exceeded that of River Ganga.

\subsubsection{Steroids}

The only steroids detected in this study were androgens, detected at very low concentrations at four sites, one in the upper stretch (U-2) and the rest in the middle stretch. 4-androstenedione was found from 0.2 (U-2) to $4.5 \mathrm{ng} / \mathrm{L}$ (M-14 and M-15). Two sites near sewer outfalls contained an additional androgen, 4- androstanedienedione, at 1.2 and $15.5 \mathrm{ng} / \mathrm{L}$, for sites M-7 and M- 15, respectively. Out of two detected steroids, the maximum concentration of 4-androstenedione was 10 fold higher than the concentration reported for the Koyama river basin, Japan (Chang et al., 2008) and $\sim 7$ fold the rivers in Beijing (Sun et al., 2015). Maximum concentrations in the influent of a Canadian wastewater treatment plant were $\sim 16$ times the concentration in this study ( $74 \mathrm{ng} / \mathrm{L}$ ), though it was not detectable in effluent and below limits of quantitation in the river (Goeuryet al., 2019) (Table S5c).

\subsubsection{Caffeine}

Caffeine can serve as a potential chemical marker for untreated human wastewater contamination of surface waters (Buerge et al., $2003 ; 2006$ ; Hillebrand et al., 2012), and is one of the prime indicators used to assess the efficiency of wastewater treatment plants producing clean recycled water (SAWPA, 2015). The higher aqueous solubility of caffeine results in it's movement in the water column rather than partitioning into the sediment phase (Bradley et al., 2007). The caffeine concentration ranges in the upper and middle stretch were 10-fold higher than in the lower stretch. Mean and ranges of measured caffeine concentrations in each stretch were: upper $0.3 \pm 0.48(0.03-1.33 \mu \mathrm{g} / \mathrm{L})$, middle $1.04 \pm 1.09(0.04-3.36 \mu \mathrm{g} / \mathrm{L})$, lower $0.11 \pm 0.26(0.09-0.91)$, and wetland $0.3 \pm 0.67(0.02-1.67 \mu \mathrm{g} / \mathrm{L})$. Maximum mean concentration of caffeine was observed in the middle stretch of River Ganga $(1 \mu \mathrm{g} / \mathrm{L})$ and is 


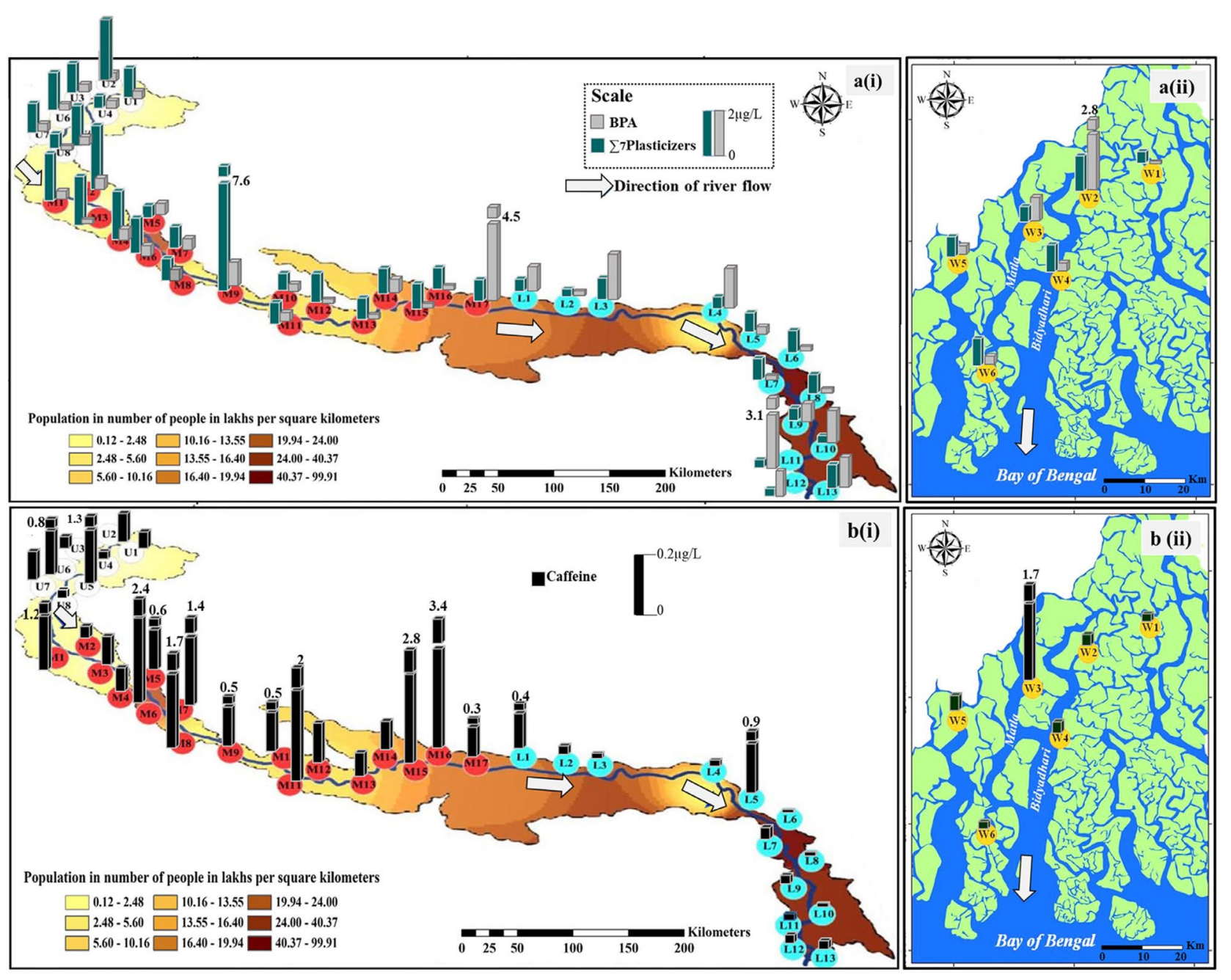

Fig. 2. Spatial distribution of (a) seven plasticizers and BPA (i) along the River Ganga (ii) Sundarban wetland and (b) caffeine (i) along the River Ganga (ii) Sundarban wetland.

comparable with the rivers from Hebei Province (Zhang et al., 2018b) and Baiyangdian Lake in China (Zhang et al., 2018a), Thames River in UK (Nakada et al., 2017), Danube River in Germany (Milić et al., 2018) and Guadiamar River in South Spain (Garrido et al., 2016) (Table S5d). However, the highest concentration in the present study $(3.4 \mu \mathrm{g} / \mathrm{L})$ (Fig. 2b) was slightly higher than River Yamuna (Mutiyar et al., 2018) and about three fold higher than the previous report from River Ganga (Sharma et al., 2019). In contrast, the highest concentration in the present study was one-third of that reported in the Umgeni River in South 
Africa (Matongo et al., 2015) and one-fifth the Jundai River in Brazil (de Sousa et al., 2018).

\subsection{Spatial distribution and sources of EDCs and caffeine}

The spatial distribution of plasticizers, BPA and caffeine are shown in Fig. $2 \mathrm{a}$ and $2 \mathrm{~b}$. Compositional profiles of those compounds with more than $85 \%$ detection frequency have been segregated in each component of site-wise PCA with best fitting ( $\left.\mathrm{R}^{2}>0.64-0.98\right)$. Sites with dominance of major PAEs (DEHP and DnBP), BPA and caffeine were loaded in PC-1, -2 and -3 , respectively (Figure S4). PC-1, PC-2 and PC-3 accounted for $57 \%, 27 \%$ and $13 \%$ of the total variance, respectively.

\subsection{1. $P C-1$}

Of the individual plasticizers, the present study found the two highest mean concentrations for DEHP and DnBP. Sites covering all regions of the river and wetlands have been represented in PC- 1 (Fig. 2a (i) and (ii)). Associated land and river use of sites in PC-1 were dominated by tourist spots supporting a huge transient population, with DnBP as the largest contributing phthalate (Figure S4). Predominance of DnBP over DEHP concentration in the upper stretch indicates the source of pollution is not solely the plastic manufacturing industry, as it is responsible for dominant DEHP release (Zeng et al., 2008). Plastic waste contributes $8 \%$ of the total solid waste in India (TERI, 2018), with $40 \%$ of the discarded waste stemming from single-use plastic items. Before the ban of single-use plastics in India, usage and unregulated disposal of single-use plastic items particularly polyethylene (PE) bags at tourist sites was a regular practice. Leaching of DnBP from PE-bags, especially ones with a lower thickness $(10 \mu \mathrm{m})$, has been well documented (Paluselli et al., 2018). The highest average concentration of plasticizers was found in the middle stretch, possibly resulting from the maximum discharge of domestic sewage in the Ganga (Sharma et al., 2019). In the middle stretch, highly significant correlation $\left(\mathrm{R}^{2}=0.89 ; p<0.01\right)$ between the quantity of domestic wastewater released through open drains and the concentration of plasticizers is in line with a previous study from China (Wu et al., 2009). Interestingly, the outlier in the middle stretch (site M-9, Allahabad) had the highest concentration of DEHP $(6.31 \mu \mathrm{g} / \mathrm{L})$ and contributed to $>95 \%$ of the summed plasticizers. This site represents 
a well-known tourist destination and the meeting point of three rivers: Ganga, Yamuna and Saraswati. We suspect that the DEHP level in this site is most likely associated with the leaching process from extensive dumping of plastic waste and polyethylene terephthalate (PET) bottles, particularly those made of recycled plastic (Keresztes et al., 2013). It is to be noted that this site was significantly different $(p<0.05)$ from other sites in the middle stretch and sites loaded in PC-1. Furthermore, in the recent past this site has been reported to be one of the most polluted sites in River Ganga, and unfit for drinking purposes (ENVIS, 2016).

Unlike the middle stretch, the sites from lower stretch of Ganga loaded in PC-1 are from the suburban districts of Hooghly and Howrah (L6L10), with higher concentration of DEHP over DnBP (3:1) (Fig. 2a (i)). A prime tourist location in the wetland, Bonnie Camp (W-6, $1.5 \mu \mathrm{g} / \mathrm{L}$ ) was found with elevated concentration of PAEs (Fig. 2a (i) and (ii)). DMP, DnBP, DEHP and DnOP were found in such tourist spots whereas DEP, BBP and DEHA were not detected at two pristine wetland sites (W-1 and W-6). Leaching of such plasticizers, predominantly DnBP and DEHP, has been associated with leaching from discarded plastic waste (Fatoki and Vernon, 1990). In addition, fishing nets and aquaculture activities have been implicated as potential sources of such plasticizers (Gardon et al., 2020). However, higher loading of DEHP in the aforementioned suburban sites (L6-L10) can be also attributed to the release of industrial sludge (Chakraborty et al., 2019b) and surface run-off of openly burnt plastic waste (Chakraborty et al., 2019a). Relatively low DEHP concentrations in the surface water of Sundarban may be a reflection of lower inputs in the wetland region. Hence, the source for plasticizers in this study may be associated with the unregulated disposal of used PET bottles and dumping of waste plastic from commercial products and industrial wastes along the river bank.

\subsection{2. $P C-2$}

Of the sites segregated into PC-2, 75\% were urban and industrial sites from the middle and lower stretches of river Ganga and contributed more than two-third concentration of BPA in this study (Figure S4). More than half of the total BPA concentration in this study was contributed by the urban sites of Kolkata city (sites L-11 through L-13) (Fig. 2a (i) and (ii)). Sites in the urban district of Kolkata (sites L-12 and L-13) and Sundarban wetland (W-2) segregated in this component are major tourist 
spots. The second highest level of BPA in this study was observed at a holy tourist spot, Dakhineshwar in North 24 Parganas district (site L-11, $3.1 \mu \mathrm{g} / \mathrm{L}$ ) (Fig. 2a (i)). The lower stretch of Ganga with high population density has the second highest per capita consumption of plastic, with up to 500 tons of plastic waste per day for India as a whole. BPA has been found to leach from various plastic wastes after only two weeks in water (Yamamoto and Yasuhara, 1999). This would indicate that in addition to untreated industrial effluents, a secondary source of BPA in PC-2 could be leachate from plastic litter, especially with the high ambient temperature associated with the region's tropical climate.

The highest levels of BPA occurred in the industrial corridor of Howrah district in the lower stretch (sites L-9 and L-10) and one site in Varanasi (site $\mathrm{M}-17$ ) in the middle stretch (Fig. 2a (i)). M-17 is situated $0.5 \mathrm{~km}$ downstream of an opium factory and receives industrial and domestic wastes. At this site, high concentration of various water quality parameters such as $\mathrm{pH}$, total dissolved solids, total suspended solids, electrical conductivity, chemical oxygen demand, coliform bacteria and heavy metals have been reported due to the proximity of this site to an open sewer (Singh et al., 2007 ; Yadav, 2016). Being an intermediate compound used as a binding, plasticizing, and hardening agent in plastics, paints/lacquers, binding materials, and filling materials (Chen et al., 2019), there is a higher probability that BPA is from industrial discharges and likely to serve as a potential point source in the lower and middle stretch of Ganga. Other possible sources of BPA in the middle and lower stretch of Ganga may stem from the widespread use and release of BPA in its un-polymerized free form or from BPA-based products into the untreated effluent from the industries.

\subsection{3. $P C-3$}

Caffeine used as a wastewater indicator has been loaded in PC-3. The highest concentration of caffeine in the riverine region was observed at Varanasi (M-16, $3.4 \mu \mathrm{g} / \mathrm{L}$ ) followed by M-15 and M-11 (Fig. 2b (i). M-16 is located downstream of a sewer outlet in Varanasi. Elevated caffeine concentrations between the Kanpur and Allahabad stations (M5-M10) correspond to the huge amount of wastewater (3019 MLD) directly released into the river (CPCB, 2013). This area is the 2nd highest producer of domestic sewage (10.7 MLD) in the state of Uttar Pradesh. Nearly three fourth of sites loaded in PC-3 were from Uttar Pradesh (middle 
river stretch) and is dominated by the stations from middle stretch (near Kanpur, Allahabad and Varanasi) (Fig. 1 \& Fig. 2). While Uttar Pradesh ranks first in the country for the generation of domestic wastewater (7144 MLD), the treatment plant capacity treats only $30 \%$ of the raw volume generated. Raw domestic wastewater is released via forty five major open drains contributing to $57 \%$ of the wastewater flow and high level of biological oxygen demand (BOD) in River Ganga (ENVIS, 2018). The close proximity $(<100 \mathrm{~m})$ to a sewer outfall may explain the elevated caffeine concentrations at site M-17. Elevated caffeine concentrations were also found at well-known tourist destinations in the upper stretch at Haridwar (site-U-5 \& U-6) and along the Matla river in SBW (site W-3, Jharkhali) (Fig. 2b (i) and (ii)). In spite of the presence of high transient populations, there are no functional treatment plants at these locations. Hence, the presence of caffeine in surface water of the Ganga and Matla rivers might have resulted from human wastes from homeless encampments, storm-water runoff containing untreated wastewater, beverage waste released from trash receptacles, and other anthropogenic activities.

\subsection{Estrogenicity: measured and theoretical estimates}

Measured estrogenic activity for each sampling point has been shown in Fig. 1. Table 2 reports the E2Eqs of each chemical calculated from EScreen and yeast assay (Cespedes et al., 2005).

\subsubsection{Measured Bio E2Eq and theoretical ChemE2Eq}

When evaluating E2Eqs obtained from an in-vitro assay, the estrogenicity of specific chemicals have been evaluated. The relative estrogenicity of estrogens, plasticizers and BPA using the E-screen in this study are reported in Table 2 and Fig. 1. Natural estrogens such as estrone, the $\alpha$ isomer of E2, and estriol are 1/10 to 1/100 as active as E2 in the E-Screen (Alvarez et al., 2013), while BPA and phthalates are much less estrogenic ( $\sim 1 / 10,000$ to $1 / 2.5$ million). Conley et al., 2017 , thoughtfully addressed the different sensitivities of various chemicals in different in-vitro estrogenicity assays, and how BioE2Eqs should be interpreted in conjunction with chemical analyses and knowledge of potential point sources impacting waters. Most recently, BioE2Eq concentrations from in-vitro assays as low as $0.1 \mathrm{ng} / \mathrm{L}$ were of environmental concern (Hubbard et 
al., 2020), based on activity and assuming the presence of the synthetic chemical component of birth control pills (ethinyl estradiol).

Mean coefficient of variation of samples with BioE2Eqs $>0.05 \mathrm{ng} / \mathrm{L}$ was $11.4 \%$. When water samples with elevated estrogenic activity were evaluated in a second experiment to confirm estrogen receptor dependence of proliferation, Bio E2Eqs were on average $98 \%$ of previously measured E2Eqs. Only two sites had BioE2Eqs that exceeded the pNEC for E2 in fish, both from samples taken from sites in the middle stretch, and at sites of sewer outfalls (BioE2Eqs of 3.87 and $1.55 \mathrm{ng} / \mathrm{L}$, for M-11 and M-15, respectively). Water from sewer outfalls is typically untreated raw sewage, and atypical of what is discharged from wastewater treatment plants in developed countries. While these values exceeded the pNEC, they fall below $10 \mathrm{ng} / \mathrm{L}$, the proposed lowest observable effect (pLOEC) for E2 on fish (Caldwell et al., 2012). The next highest BioE2Eq was found in water from the upper stretch (U-5, $0.58 \mathrm{ng} / \mathrm{L}$ E2Eqs), a site with no known sewer outfall. A third site on the middle stretch associated with a sewer outfall was M-7, which had BioE2Eq of $0.28 \mathrm{ng} / \mathrm{L}$. These lower values are quite similar to the values reported by Conley et al., 2017 for source water for drinking water treatment plants from 25 locations in the United States (maximum 0.47 ng/L E2Eqs, mean $0.19 \pm 0.13$ ng/L, T47D-KBluc assay). The concentration of BioE2Eqs downstream from the sewer outfalls fell approximately 10-fold (M-11 and M-15), while the site downstream from the M-7 outfall remained elevated.

We have examined the relationship between concentrations of estrogenic compounds in water from the river and wetland with total estrogenicity. While it would be assumed that estrogens would be detected and measured chemically in water from sewer outfalls, this was not the case. This absence of measurable estrogens has often been reported in the literature, and was addressed in the work cited above by Conley et al., 2017. They reported while estrogenic activity was detectable in $66 \%$ of the water samples, $80 \%$ of the samples had estrogens below the limits of quantitation. Estrone, the most commonly detected estrogen in wastes from humans and animals, was detected in 5 of 25 samples at only 0.1 to $0.3 \mathrm{ng} / \mathrm{L}$. In the E-Screen these concentrations would result in BioE2Eq of $0.004 \mathrm{ng} / \mathrm{L}$, below the LOQ of the present study. The theoretical ChemE2Eq that would result from the concentrations of BPA and phthalates in this study, do not account for the BioE2Eq, as 


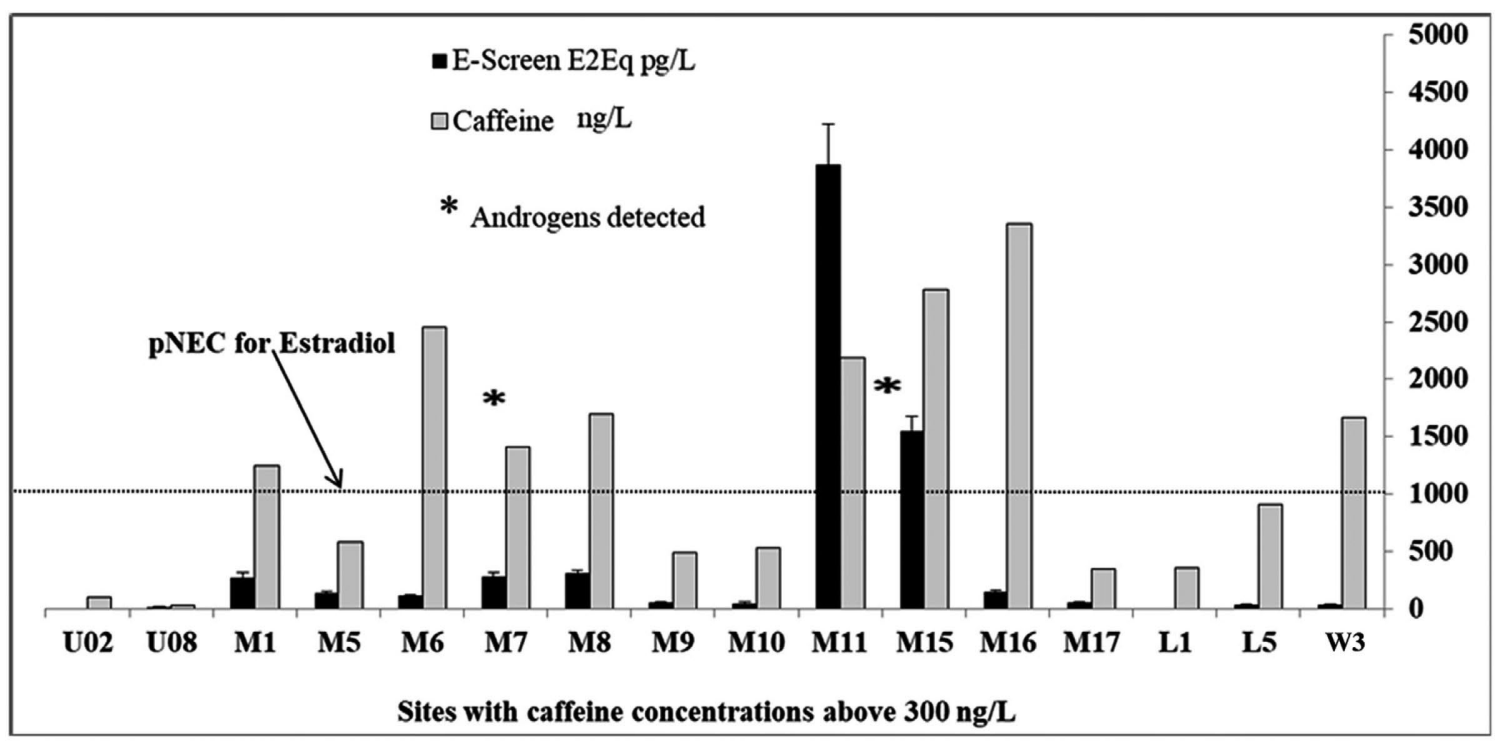

Fig. 3. E-Screen Estradiol Equivalents of sites with high caffeine concentration. Line indicates Predicted No Effect Concentration (pNEC) for estradiol in fish of $1 \mathrm{ng} / \mathrm{L}$ (Young et al., 2004), with the proposed Lowest Observable Effect Concentration of $10 \mathrm{ng} / \mathrm{L}$ (Caldwell et al., 2012).Extract from Site M6 resulted in cellular toxicity.

clearly shown in Figure S5. Two sites with the highest measured BioE2Eqs were omitted from analysis, resulting in an $\mathrm{R}^{2}<0.02$ between theoretical ChemE2Eq and BioE2Eq using either the presently determined E-Screen factors for the plasticizers, or those from Céspedes et al., 2005 for the YES assay. Caffeine was a good indicator of wastewater input and potential estrogenic activity (Fig. 3). The correlation between BioE2Eq and caffeine concentrations divided by ten had a $\mathrm{R}^{2}$ of 0.21 . After, excluding sites with higher BioE2Eqs (M11 and M15), $\mathrm{R}^{2} \mathrm{im}$ proved to 0.31. Only three sites out of 44 sites tested had BioE2Eq $\geq 50$ $\mathrm{pg} / \mathrm{L}$ without an elevation of caffeine concentration ( $<90 \mathrm{ng} / \mathrm{L})$. Site $\mathrm{M}-4$ had $78 \mathrm{pg} / \mathrm{L}$ BioE2Eq and was in proximity to agricultural lands, where presumably livestocks were responsible for the elevation of activity. Site L-3 had $50 \mathrm{pg} / \mathrm{L}$ of BioE2Eq and could be associated with bathing activities, thereby having less sewage-type waste, in which caffeine would be present ( $40 \mathrm{ng} / \mathrm{L}$ ). Site L-13 had $71 \mathrm{pg} / \mathrm{L}$ of BioE2Eq, while caffeine concentrations was only $20 \mathrm{ng} / \mathrm{L}$.

While no samples contained detectable levels of estrogens, androgens were detected at three sites in the middle stretch (M-7, M-14, and M-15) all in and around sewer outfalls (site M-7 Jajmau, M-15, Chaukighat). It 
is noteworthy that these sites have elevated BioE2Eqs. In addition to human waste as a source of androgens at M-7, is waste from the slaughtered animals processed by proximal tanneries, as nearly 403 tanneries are there in the Jajmau area. These tanneries produce 50 MLD of wastewater, only $18 \%$ of which is treated, the rest being discharged directly into the river. In the upper stretch, androgens were detected at the only site (U-2) where cellular toxicity was found in the E-Screen assay (Fig. $3)$. While caffeine concentration was low here (10 ng/L), cellular toxicity precluded any measurement of Bio E2Eqs. Detected androgens could be the result of endogenously-produced compounds or indicative of synthetic pharmaceutical usage.

\subsubsection{Theoretical ChemYES}

Estimated ChemYES was highest for DEHP concentrations, followed by DnBP, which is in accordance with previous reports (DomínguezMorueco et al., 2014). Such high theoretical estrogenicity values reveal the potential risk to the aquatic environment and humans exposed to PAEs contamination in the area. In the case of BPA, all sites showed very high theoretical estrogenic potential, especially at site M-17 (Ghazipur) where the highest concentration of BPA was recorded. The ChemE2Eq and ChemYES were similar, but actual measured BioE2Eqs (tested by E-Screen) were typically lower than both the theoretical estrogenicity values.

Two explanations are possible for these differences. First, it is very likely that the rapid degradation of natural estrogens in conjunction with their typical extremely low concentrations (1-100 ng/L) in surface waters, resulted in lack of detection and consequently under estimation of the theoretical E2Eq. If estrogens, and specifically estrone, had been detected, then E-Screen and YES estimates of E2Eq would likely have been more disparate, as estrone is more active in the yeast assay than in the E-Screen (potency factor $40 \%$ vs $12 \%$ of E2, respectively) (Alvarez et al., 2013). The second factor that could result in lower observed versus theoretical or calculated concentrations relates to the effect of competition for the $\mathrm{E} 2$ receptor. Just as has been accepted in whole body physiology that the sum of multiple agonists with differential activity is not always additive, cell exposure to a mixture of estrogens with differential estrogenic potential does not always result in an additive proliferation (Shappell, 2018). Therefore, it should be expected 


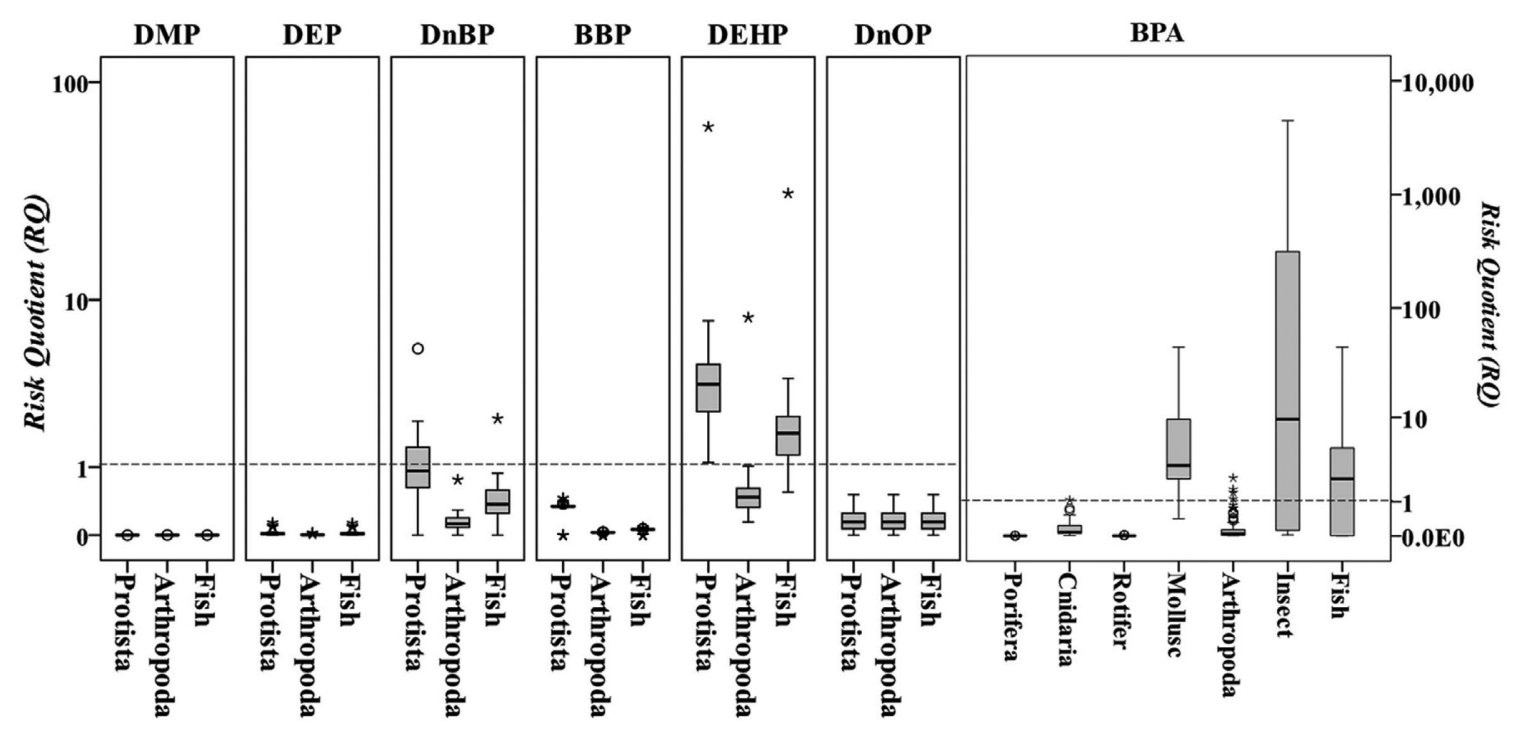

Fig. 4. Box-whisker plots showing the range of ecotoxicological risk estimated from surface water concentrations of River Ganga and Sundarban wetland for (a) plasticizers (DMP, DEP, DnBP, BBP and DEHP) and (b). BPA. (Dashed line indicates hazard limit given by USEPA; Asterisks indicates the maximum outlier).

that the presence of higher concentrations of weaker phthalates might blunt the expected estrogenic effect of stronger compounds such as BPA. Such an occurrence may explain findings at site M-17, where the highest concentrations of BPA was found $(4.5 \mu \mathrm{g} / \mathrm{L})$ yet BioE2Eq was only $52 \mathrm{pg} / \mathrm{L}$, in contrast to the predicted ChemE2Eq of $342 \mathrm{pg} / \mathrm{L}$. While the E-Screen cannot predict whole organism effects in a mixture, cellular proliferation in the presence of a complex mixture is more reflective of an organismal response than using the sum of single chemical concentrations times their respective $\mathrm{EC}_{50}$ 's.

\subsection{Ecotoxicological risk assessment}

As shown in Fig. 4 screening level risk assessment was estimated for a wide variety of trophic level organisms for PAEs and BPA in Ganga and SBW. The Sundarban wetland houses very rare and valuable species of flora and fauna and is a UNESCO World Heritage site. Protista have the highest risk quotient for the classes considered, and reflect their lower pNECs (1/2 to $1 / 5$ lower). Both the upper stretch and the wetlands contained sites with the highest risk for Protists (some values with RQ > 1), 
while fishes were at medium risk $(\mathrm{RQ}>0.1)$. Arthropods were the least sensitive class, a reflection of their higher pNECs, especially for DEP. DEHP has both the highest concentrations in the Ganga, and the lowest pNEC for all three classes of organisms, thereby indicating the phthalate of highest concern in the River Ganga. In the wetland, mean concentration of DnBP was higher than DEHP and DEP, and with a lower pNEC than DEP's, perhaps it is the phthalate of greater concern for this region. Interestingly, though DnOP in this study was present at very low concentrations, the pNEC for Lepomis macrochius (blue gill or bream) was as low as that for BPA ( $0.1 \mu \mathrm{g} / \mathrm{L}$ for Cyprinus carpio), indicating it is a phthalate that might result in higher than expected risk. Dietary intake has been found to be the primary exposure pathway for humans, due to the bioaccumulation of phthalate esters in food chains and the frequent use or unintended presence of phthalates in various food materials during processing, transport and storage (Staples et al., 1997 ; USEPA, 2007). Positive correlation has been reported between the concentration of PAEs in human body and fish consumption in China (Cheng et al., 2013).

While insects appear to be at a greatest risk $(R Q s \geq 100)$ from BPA in the Ganga and SBW, in part this is due to an extremely low pNEC of the insect Chrironomus riparius. Mollusks and fishes were at the next highest level of estimated risk $(1>R Q<10)$, again reflecting their pNEC for BPA $(0.1 \mu \mathrm{g} / \mathrm{L}$ for mollusk, medaka and carp). While the concentrations detected in this study are, even at the highest, more than 200 times less than the concentration $(1 \mathrm{mg} / \mathrm{L})$ that can induce super feminization syndrome in Marisa cornuarietis (Oehlmann et al., 2006) and altered germ cell development in fathead minnow (Oehlmann et al., 2008). The impact of BPA on fish in the River Ganga should be considered in light of the fact that they reflect $20 \%$ of the 143 different types of freshwater fish reported in India. As reported for phthalates, BPA was found to bioaccummulate in the aquatic organisms (Careghini et al., 2015). Because carps caught from the River Ganga are a common food source, high concentrations of BPA, particularly in the lower stretch of Ganges may pose not only an ecotoxicological risk to fish, but also pose an indirect impact on human health. 


\section{Conclusion}

This study has documented the occurrence of a variety of estrogenic chemicals in River Ganga, compared theoretical estrogenic activity as E2Eq to measured estrogenicity of waters via E-Screen, examined the potential risk to various life forms, conjectured the sources, and compared measured concentrations to those reported in other regions of the world. While environmental concentrations of BPA and PAEs were measurable, neither these chemicals nor the estrogenic activity of the river and wetland appear to pose a grave risk to wildlife or humans. There were no obvious correlations between sites with higher Bio E2Eqs and ecotoxicological risk to species based on BPA and PAE concentrations. The equivalent pNEC for E2 exceeded in only 2 samples and no sample exceeded the LOEC for E2. The finding of elevated caffeine concentrations at all but 3 sites where higher E2Eq were found, suggests that it is a useful indicator of human waste inputs. In River Ganga, from the phthalate and BPA sources of contamination associated with plastic litter disposal, it appears that BPA remains the xenobiotic chemical of highest concern in this study, though its estrogenic effects were clearly evident in only 2 samples. While the concentrations of chemicals found in this study are lower than many reported in other regions of the world, as well as other rivers in India, this study identifies potential point sources of contamination and provides a benchmark for future studies monitoring chemical contamination of the Ganga. Based on our findings on identification and quantitation of EDCs and estrogenicity of the water samples from River Ganga and Sundarban wetland, future remediation effort s can be taken in the area of greatest need. 
Competing Interest The authors declare that they have no known competing financial interests or personal relationships that could have appeared to influence the work reported in this paper.

Acknowledgments This work was supported by Selective Excellence initiative of SRM Institute of Science and Technology under signature programs competition, criteria for academic excellence, SRM Institute of Science and Technology Kattankulathur campus and Water Advanced Research and Innovation (WARI) Fellowship Program (IUSSTF/ WARI Fellowship/F-5-2016) supported by the Department of Science and Technology, Government of India, the Daugherty Water for Food Institute (DWFI), University of Nebraska-Lincoln and the Indo-US Science and Technology Forum (IUSSTF) awarded to Dr. Chakraborty. Gratitude is extended to Patrick Harland and Lloyd Billey for their contributions in E-Screen measurements of various chemicals in order to derive relative estradiol equivalency factors for chemicals found to be present in water samples, as well as determination of water sample E2Eqs.

Supplementary materials Supplementary material associated with this article are attached to the archive record for this document.

\section{References}

Alvarez, D.A., Shappell, N.W., Billey, L., Bermudez, D.S., Wilson, V.S., Kolpin, D.W., Perkins, S.D., Evans, N., Foreman, W.T., Gray, J.L., 2013. Bioassay of estrogenicity and chemical analyses of estrogens in streams across the United States associated with livestock operations. Water Res. 47 (10), 3347-3363.

Basheer, C., Parthiban, A., Jayaraman, A., Lee, H.K., Valiyaveettil, S., 2005. Determination of alkylphenols and bisphenol-A: a comparative investigation of functional polymer-coated membrane microextraction and solid-phase microextraction techniques. J. Chromatogr. A 1087 (1), 274-282.

Bradley, P.M., Barber, L.B., Kolpin, D.W., McMahon, P.B., Chapelle, F.H., 2007. Biotransformation of caffeine, cotinine, and nicotine in stream sediments: implications for use as wastewater indicators. Environ. Toxicol. Chem. 26 (6), 1116-1121.

Buerge, I.J., Poiger, T., Müller, M.D., Buser, H.-R., 2003. Caffeine, an anthropogenic marker for wastewater contamination of surface waters. Environ. Sci. Technol. 37 (4), 691-700.

Buerge, I.J., Poiger, T., Müller, M.D., Buser, H.-.R., 2006. Combined sewer overflows to surface waters detected by the anthropogenic marker caffeine. Environ. Sci. Technol. 40 (13), 4096-4102.

Caldwell, D.J., Mastrocco, F., Anderson, P.D., Länge, R., Sumpter, J.P., 2012. Predictedno-effect concentrations for the steroid estrogens estrone, $17 \beta$-estradiol, estriol, and $17 \alpha$-ethinylestradiol. Environ. Toxicol. Chem. 31 (6), 1396-1406.

Careghini, A., Mastorgio, A.F., Saponaro, S., Sezenna, E., 2015. Bisphenol A, nonylphenols, benzophenones, and benzotriazoles in soils, groundwater, surface water, sediments, and food: a review. Environ. Sci. Pollut. Res. 22 (8), 5711-5741. 
Céspedes, R., Lacorte, S., Raldúa, D., Ginebreda, A., Barceló, D., Piña, B., 2005.

Distribution of endocrine disruptors in the Llobregat River basin (Catalonia, NE Spain). Chemosphere 61 (11), 1710-1719.

Chakraborty, P., Khuman, S.N., Selvaraj, S., Sampath, S., Devi, N.L., Bang, J.J., Katsoyiannis, A., 2016. Polychlorinated biphenyls and organochlorine pesticides in River Brahmaputra from the outer Himalayan Range and River Hooghly emptying into the Bay of Bengal: occurrence, sources and ecotoxicological risk assessment. Environ. Pollut. 219, 998-1006.

Chakraborty, P., Mukhopadhyay, M., Sampath,S., Ramaswamy, B.R., Katsoyiannis, A., Cincinelli, A., Snow, D.,2019a. Organic micropollutants in the surface riverine sediment along the lower stretch of the transboundary river Ganga: occurrences, sources and ecological risk assessment. Environ. Pollut. 249, 1071-1080.

Chakraborty, P., Sampath, S., Mukhopadhyay, M., Selvaraj, S., Bharat, G.K., Nizzetto, L., 2019b. Baseline investigation on plasticizers, bisphenol A, polycyclic aromatic hydrocarbons and heavy metals in the surface soil of the informal electronic waste recycling workshops and nearby open dumpsites in Indian metropolitan cities. Environ. Pollut. 248, 1036-1045.

Chang, H., Wu, S., Hu, J., Asami, M., Kunikane, S., 2008. Trace analysis of androgens and progestogens in environmental waters by ultra-performance liquid chromatography-electrospray tandem mass spectrometry. J. Chromatogr. A 1195 (1-2), 44-51.

Chen, H., Mao, W., Shen, Y., Feng, W., Mao, G., Zhao, T., Yang, L., Yang, L., Meng, C., Li, Y, 2019. Distribution, source, and environmental risk assessment of phthalate esters (PAEs) in water, suspended particulate matter, and sediment of a typical Yangtze River Delta City, China. Environ. Sci. Pollut. Res. 1-11.

Cheng, Z., Nie, X.-.P., Wang, H.-.S., Wong, M.-H., 2013. Risk assessments of human exposure to bioaccessible phthalate esters through market fish consumption. Environ. Int. 57, 75-80.

Conley, J.M., Evans, N., Mash, H., Rosenblum, L., Schenck, K., Glassmeyer, S., Furlong, E.T., Kolpin, D.W., Wilson, V.S., 2017. Comparison of in vitro estrogenic activity and estrogen concentrations in source and treated waters from 25 US drinking water treatment plants. Sci. Total Environ. 579, 1610-1617.

CPCB 2013. Central Pollution Control Board report, 2013. "Pollution Assessment of River Ganga”, Available at: http://www.nationalwatermission.gov.in/sites/ default/files/waterwiki/2.pdf ; Accessed on 28th March 2020.

CWC 2017. Central Water Commission report, 2017. Available at: http://www. indiaenvironmentportal.org.in/files/file/Ganga $\% 20$ water $\% 20$ quality $\% 20$ Year\%20book\%202016-17.pdf , Accessed on 28th March 2020.

D’Alessio, M., Onanong, S., Snow, D.D., Ray, C., 2018. Occurrence and removal of pharmaceutical compounds and steroids at four wastewater treatment plants in Hawai'i and their environmental fate. Sci. Total Environ. 1360-1370 631-632.

Dargnat, C., Teil, M.-.J., Chevreuil, M., Blanchard, M., 2009. Phthalate removal throughout wastewater treatment plant: case study of Marne Aval station (France). Sci. Total Environ. 407 (4), 1235-1244. 
de Sousa, D.N.R., Mozeto, A.A., Carneiro, R.L., Fadini, P.S., 2018. Spatio-temporal evaluation of emerging contaminants and their partitioning along a Brazilian watershed. Environ. Sci. Pollut. Res. 25 (5), 4607-4620.

Ding, W.H., Wu, C.Y., 200 0. Determination of Estrogenic Nonylphenol and Bisphenol a in River Water by solid-phase extraction and gas chromatography-mass spectrometry. J. Chin. Chem. Soc. 47 (5), 1155-1160.

Domínguez-Morueco, N., González-Alonso, S., Valcárcel, Y., 2014. Phthalate occurrence in rivers and tap water from central Spain. Sci. Total Environ. 500, 139-146.

Dong, J., Li, X., Liang, R., 2009. Bisphenol A pollution of surface water and its environmental factors. J. Ecol. Rural Environ. 25 (2), 94-97.

EC, 1994. The Commission of European Communities, concerning the first list of priority substances as foreseen under Council Regulation (EEC) No 793/93. Off. J. Eur. Commu. L 131, 3-4.

EC, 1995. The Commission of European Communities, Concerning the second list of priority substances as foreseen under Council Regulation (EEC) No 793/93. Off. J. Eur. Commun. L 231, 18-19.

EC, 1997. The commission of European communities, concerning the third list of priority substances as foreseen under Council Regulation (EEC) No 793/93. Off. J. Eur. Commun. L 025, 13-14.

ENVIS 2018. Environmental information system, 2018. Summary of identified and Priority Drains Monitored during Pre-Monsoon, 2018 (Discharged into River Ganga); Available at: http://www.sulabhenvis.nic.in/Database/STST gangabasin 2088.aspx ; Accessed on 28th January 2020.

ENVIS, 2016. Environmental information system, Ganga bulletin, 2016. Available at: http://cpcbenvis.nic.in/envis newsletter/Ganga\%20Samachar\%202016\%20 December\%20ebook.pdf; Accessed on 28th March 2020.

Fatoki, O.S., Vernon, F., 1990. Phthalate esters in rivers of the Greater Manchester area, UK. Sci. Total Environ. 95, 227-232.

Gao, D., Li, Z., Wen, Z., Ren, N., 2014. Occurrence and fate of phthalate esters in fullscale domestic wastewater treatment plants and their impact on receiving waters along the Songhua River in China. Chemosphere 95, 24-32.

Gardon, T., Huvet, A., Paul-Pont, I., Cassone, A.L., Koua, M.S., Soyez, C., Jezequel, R., Receveur, J., Le Moullac, G., 2020. Toxic effects of leachates from plastic pearlfarming gear on embryo-larval development in the pearl oyster Pinctada margaritifera. Water Res., 115890.

Garrido, E., Camacho-Muñoz, D., Martín, J., Santos, A., Santos, J.L., Aparicio, I., Alonso, E., 2016. Monitoring of emerging pollutants in Guadiamar River basin (South of Spain): analytical method, spatial distribution and environmental risk assessment. Environ. Sci. Pollut. Res. 23 (24), 25127-25144.

Gatidou, G., Thomaidis, N.S., Stasinakis, A.S., Lekkas, T.D., 2007. Simultaneous determination of the endocrine disrupting compounds nonylphenol, nonylphenol ethoxylates, triclosan and bisphenol $\mathrm{A}$ in wastewater and sewage sludge by gas chromatography-mass spectrometry. J. Chromatogr. A 1138 (1-2), 32-41. 
Goeury, K., Duy, S.V., Munoz, G., Prévost, M., Sauvé, S., 2019. Analysis of Environmental Protection Agency priority endocrine disruptor hormones and bisphenol A in tap, surface and wastewater by online concentration liquid chromatography tandem mass spectrometry. J. Chromatogr. A 1591, 87-98.

Gomez-Hens, A., Aguilar-Caballos, M., 2003. Social and economic interest in the control of phthalic acid esters. TrAC Trends Anal. Chem. 22 (11), 847-857.

GRBEMP, 2013. Ganga River Basin Environmental Management Plan, 2013. Interim Report: IIT Consortium August 2013; Available at http://mowr.gov.in/sites/ default/files/GRBEMPInterimReport_2.pdf

Hahladakis, J.N., Velis, C.A., Weber, R., Iacovidou, E., Purnell, P., 2018. An overview of chemical additives present in plastics: migration, release, fate and environmental impact during their use, disposal and recycling. J. Hazard. Mater. 344, 179-199.

Hermabessiere, L., Dehaut, A., Paul-Pont, I., Lacroix, C., Jezequel, R., Soudant, P., Duflos, G., 2017. Occurrence and effects of plastic additives on marine environments and organisms: a review. Chemosphere 182, 781-793. Hillebrand, 0., Nödler, K., Licha, T., Sauter, M., Geyer, T., 2012. Caffeine as an indicator for the quantification of untreated wastewater in karst systems. Water Res. 46 (2), 395-402.

Huang, Y., Wong, C., Zheng, J., Bouwman, H., Barra, R., Wahlström, B., Neretin, L., Wong, M., 2012. Bisphenol A (BPA) in China: a review of sources, environmental levels, and potential human health impacts. Environ. Int. 42, 91-99.

Hubbard, L.E., Givens, C.E., Griffin, D.W., Iwanowicz, L., Meyer, M.T., Kolpin, D.W., 2020. Poultry litter as potential source of pathogens and other contaminants in groundwater and surface water proximal to large-scale confined poultry feeding operations. Sci. Total Environ., 139459.

Keresztes, S., Tatár, E., Czegeny, Z., Záray, G., Mihucz, V.G.,2013. Study on the leaching of phthalates from polyethylene terephthalate bottles into mineral water. Sci. Total Environ. 458, 451-458.

Lee, C.-.C., Jiang, L.-.Y., Kuo, Y.-.L., Hsieh, C.-.Y., Chen, C.S., Tien, C.-.J., 2013. The potential role of water quality parameters on occurrence of nonylphenol and bisphenol A and identification of their discharge sources in the river ecosystems. Chemosphere 91 (7), 904-911.

Li, B., Hu, X., Liu, R., Zeng, P., Song, Y., 2015. Occurrence and distribution of phthalic acid esters and phenols in Hun River Watersheds. Environ. Earth Sci. 73 (9), 5095-5106.

Li, R., Liang, J., Gong, Z., Zhang, N., Duan, H., 2017. Occurrence, spatial distribution, historical trend and ecological risk of phthalate esters in the Jiulong River, Southeast China. Sci. Total Environ. 580, 388-397.

Matongo, S., Birungi, G., Moodley, B., Ndungu, P., 2015. Occurrence of selected pharmaceuticals in water and sediment of Umgeni River, KwaZulu-Natal, South Africa. Environ. Sci. Pollut. Res. 22 (13), 10298-10308.

Milić, N., Milanović, M., Radonić, J., Sekulić, M.T., Mandić, A., Orčić, D., Mišan, A., Milovanović, I., Letić, N.G., Miloradov, M.V., 2018. The occurrence of selected xenobiotics in the Danube river via LC-MS/MS. Environ. Sci. Pollut. Res. 25 (11), 11074-11083. 
Moore, M., Greenway, S., Farris, J., Guerra, B., 2008. Assessing caffeine as an emerging environmental concern using conventional approaches. Arch. Environ. Contam. Toxicol. 54 (1), 31-35.

Mutiyar, P.K., Gupta, S.K., Mittal, A.K., 2018. Fate of pharmaceutical active compounds (PhACs) from River Yamuna, India: an ecotoxicological risk assessment approach. Ecotoxicol. Environ. Saf. 150, 297-304.

Nakada, N., Hanamoto, S., Jürgens, M.D., Johnson, A.C., Bowes, M.J., Tanaka, H., 2017. Assessing the population equivalent and performance of wastewater treatment through the ratios of pharmaceuticals and personal care products present in a river basin: application to the River Thames basin, UK. Sci. Total Environ. 575, 1100-1108.

NCCR 2019. Coastal water quality, Available at: https://www.nccr.gov. in/?q=activities/coastal-water-quality Accessed on 28th March 2020.

Net, S., Dumoulin, D., El-Osmani, R., Rabodonirina, S., Ouddane, B., 2014. Case study of PAHs, Me-PAHs, PCBs, phthalates and pesticides contamination in the Somme River water, France. Int. J. Environ. Res. 8 (4), 1159-1170.

Oehlmann, J., Oetken, M., Schulte-Oehlmann, U., 2008. A critical evaluation of the environmental risk assessment for plasticizers in the freshwater environment in Europe, with special emphasis on bisphenol A and endocrine disruption. Environ. Res. 108 (2), 140-149.

Oehlmann, J., Schulte-Oehlmann, U., Oetken, M., Bachmann, J., Lutz, I., Kloas, W., Ternes, T.A., 2006. Effects of BPA in snails: Oehlmann et al. respond. Environ. Health Perspect. 114 (6), A341.

Paluselli, A., Fauvelle, V., Galgani, F., Sempéré, R., 2018. Phthalate release from plastic fragments and degradation in seawater. Environ. Sci. Technol. 53 (1), 166-175.

PRC-NS, 2002. Environmental Quality Standard For Surface Water. Ministry of Environmental Protection of the People's Republic of China and General Administration of Quality Supervision. Inspection and Quarantine of the People's Republic of China, GB 3838-2002.

Quinn, B., Gagné, F., Blaise, C., 2009. Evaluation of the acute, chronic and teratogenic effects of a mixture of eleven pharmaceuticals on the cnidarian, Hydra attenuata. Sci. Total Environ. 407 (3), 1072-1079.

Rasmussen, T.H., Nielsen, J.B., 2002. Critical parameters in the MCF-7 cell proliferation bioassay (E-Screen). Biomarkers 7 (4), 322-336.

Richards, S.M., Cole, S.E., 2006. A toxicity and hazard assessment of fourteen pharmaceuticals to Xenopus laevis larvae. Ecotoxicology 15 (8), 647-656.

SAWPA 2015. Detection of Caffeine in the Streams and Rivers within the San Diego Region: pilot Study; Available at: https://www.waterboards.ca.gov/sandiego/ water issues/programs/swamp/docs/Caffeine_FINAL_22Dec2015.pdf ; Accessed on 28th March 2020.

Schmidt, C., Krauth, T., Wagner, S., 2017. Export of plastic debris by rivers into the sea. Environ. Sci. Technol. 51 (21), 12246-12253.

Schmidt, N., Castro-Jiménez, J., Fauvelle, V., Ourgaud, M., Sempere, R., 2020. Occurrence of organic plastic additives in surface waters of the Rhône River (France). Environ. Pollut. 257, 113637. 
Selvaraj, K.K., Shanmugam, G., Sampath, S., Larsson, D.J., Ramaswamy, B.R., 2014. GC-MS determination of bisphenol A and alkylphenol ethoxylates in river water from India and their ecotoxicological risk assessment. Ecotoxicol. Environ. Saf. 99, $13-20$.

Selvaraj, K.K., Sundaramoorthy, G., Ravichandran, P.K., Girijan, G.K., Sampath, S., Ramaswamy, B.R., 2015. Phthalate esters in water and sediments of the Kaveri River, India: environmental levels and ecotoxicological evaluations. Environ. Geochem. Health 37 (1), 83-96.

Shappell, N., Billey, L., Shipitalo, M., 2016. Estrogenic activity and nutrient losses in surface runoff after winter manure application to small watersheds. Sci. Total Environ. 543, 570-580.

Shappell, N.W., 2006. Estrogenic activity in the environment: municipal wastewater effluent, river, ponds, and wetlands. J. Environ. Qual. 35 (1), 122-132.

Shappell, N.W., 2018. Use of fixed ratios in mixture studies, in vitro evidence of issues. Integr. Environ. Assess. Manage. 14 (3), 420-422.

Sharma, B.M., Bečanová, J., Scheringer, M., Sharma, A., Bharat, G.K., Whitehead, P.G., Klánová, J., Nizzetto, L., 2019. Health and ecological risk assessment of emerging contaminants (pharmaceuticals, personal care products, and artificial sweeteners) in surface and groundwater (drinking water) in the Ganges River Basin, India. Sci. Total Environ. 646, 1459-1467.

Singh, M., Singh, I.B., Müller, G., 2007. Sediment characteristics and transportation dynamics of the Ganga River. Geomorphology 86 (1), 144-175.

Smith, G.R., Burgett, A.A., 2005. Effects of three organic wastewater contaminants on American toad, Bufo americanus, tadpoles. Ecotoxicology 14 (4), 477-482.

Snow, D.D., Damon-Powell, T., Onanong, S., Cassada, D.A., 2013. Sensitive and simplified analysis of natural and synthetic steroids in water and solids using online solid-phase extraction and microwave-assisted solvent extraction coupled to liquid chromatography tandem mass spectrometry atmospheric pressure photoionization. Anal. Bioanal. Chem. 405 (5), 1759-1771.

Stachel, B., Ehrhorn, U., Heemken, O.-.P., Lepom, P., Reincke, H., Sawal, G., Theobald, N., 2003. Xenoestrogens in the River Elbe and its tributaries. Environ. Pollut. 124 (3), 497-507.

Staples, C.A., Dorn, P.B., Klecka, G.M., Sondra, T., Branson, D.R., Harris, L.R., 200 0 . Bisphenol A concentrations in receiving waters near US manufacturing and processing facilities. Chemosphere 40 (5), 521-525.

Staples, C.A., Peterson, D.R., Parkerton, T.F., Adams, W.J., 1997. The environmental fate of phthalate esters: a literature review. Chemosphere 35 (4), 667-749.

Sun, J., Luo, Q., Wang, D., Wang, Z., 2015. Occurrences of pharmaceuticals in drinking water sources of major river watersheds, China. Ecotoxicol. Environ. Saf. 117, 132-140.

Swan, S.H., 2008. Environmental phthalate exposure in relation to reproductive outcomes and other health endpoints in humans. Environ. Res. 108 (2), 177-184.

TERI 2018. Fact Sheet on plastic waste in India, 2018. Available at: https://www. teriin.org/sites/default/files/files/factsheet.pdf ; Accessed on 28th March 2020. 
USEPA 1986. Guidelines for establishing test procedures for the analysis of pollutants - Definition and procedure for the determination of the method detection limit-Revision 1.11. Electronic code of federal regulations title 40: protection of Environment(Part 136), Appendix B to Part 136-Definition and procedure for the determination of the method detection limit-revision 131.111.

USEPA 2007. United States Environmental Protection Agency (US EPA), 2007. Test methods for evaluating solid waste physical/chemical methods, SW-846, method 8270D: semivolatile organic compounds by gas chromatography/mass spectrometry (GC/MS).

USEPA 2014. United States Environmental Protection Agency, December 2014. 40 CFR Part 423, Appendix A. Available at: https://www.epa.gov/sites/production/ files/2015-09/documents/priority-pollutant-list-epa.pdf

Vilela, C.L.S., Bassin, J.P., Peixoto, R.S., 2018. Water contamination by endocrine disruptors: impacts, microbiological aspects and trends for environmental protection. Environ. Pollut. 235, 546-559.

Wei, X.-F., Linde, E., Hedenqvist, M.S., 2019. Plasticiser loss from plastic or rubber products through diffusion and evaporation. NPJ Mater. Degrad. 3 (1), 1-8.

Wu, B., Zhao, D., Zhang, Y., Zhang, X., Cheng, S., 2009. Multivariate statistical study of organic pollutants in Nanjing reach of Yangtze River. J. Hazard. Mater. 169 (1-3), 1093-1098.

Wu, X., Hong, H., Liu, X., Guan, W., Meng, L., Ye, Y., Ma, Y., 2013. Graphene-dispersive solid-phase extraction of phthalate acid esters from environmental water. Sci. Total Environ. 44 4, 224-230.

Ye, Z., Weinberg, H.S., Meyer, M.T., 2007. Trace analysis of trimethoprim and sulfonamide, macrolide, quinolone, and tetracycline antibiotics in chlorinated drinking water using liquid chromatography electrospray tandem mass spectrometry. Anal. Chem. 79 (3), 1135-1144.

Yadav, S.K.P.S., 2016. Quantitative and qualitative estimation of waste water discharge from Ghazipur city. World Rural Obser. 8 (1), 52-56 2016.

Yamamoto, T., Yasuhara, A., 1999. Quantities of bisphenol A leached from plastic waste samples. Chemosphere 38 (11), 2569-2576.

Yamazaki, E., Yamashita, N., Taniyasu, S., Lam, J., Lam, P.K., Moon, H.-.B., Jeong, Y., Kannan, P., Achyuthan, H., Munuswamy, N., 2015. Bisphenol A and other bisphenol analogues including BPS and BPF in surface water samples from Japan, China, Korea and India. Ecotoxicol. Environ. Saf. 122, 565-572.

Young, W., Whitehouse, P., Johnson, I., 2002. Proposed Predicted-No-EffectConcentrations (PNECs) For Natural and Synthetic Steroid Oestrogens in Surface Waters. Environment Agency.

Zeng, F., Cui, K., Xie, Z., Liu, M., Li, Y., Lin, Y., Zeng, Z., Li, F., 2008. Occurrence of phthalate esters in water and sediment of urban lakes in a subtropical city, Guangzhou, South China. Environ. Int. 34 (3), 372-380.

Zhang, L., Dong, L., Ren, L., Shi, S., Zhou, L., Zhang, T., Huang, Y., 2012. Concentration and source identification of polycyclic aromatic hydrocarbons and phthalic acid esters in the surface water of the Yangtze River Delta, China.. J. Environ. Sci. 24 (2), 335-342. 
Zhang, P., Zhou, H., Li, K., Zhao, X., Liu, Q., Li, D., Zhao, G., 2018a. Occurrence of pharmaceuticals and personal care products, and their associated environmental risks in a large shallow lake in north China. Environ. Geochem. Health 40 (4), 1525-1539.

Zhang, P., Zhou, H., Li, K., Zhao, X., Liu, Q., Li, D., Zhao, G., Wang, L., 2018b. Occurrence of pharmaceuticals and personal care products, and their associated environmental risks in Guanting Reservoir and its upstream rivers in north China. RSC Adv. 8 (9), 4703-4712.

Zhou, J., Liu, Y., 200 0. Kinetics and equilibria of the interactions between diethylhexyl phthalate and sediment particles in simulated estuarine systems. Mar. Chem. 71 (1-2), 165-176. 